\title{
A unique Valanginian paleoenvironment at an iron ore deposit near Zengõvárkony (Mecsek Mts, South Hungary), and a possible genetic model
}

\author{
László Bujtor \\ D epartment of Regional Geology, Geological Institute \\ of H ungary, Budapest
}

\begin{abstract}
The spatially restricted Early Valanginian iron ore (limonite) and manganese deposit at Zengõvárkony (Mecsek Mts, southern Hungary) contains a rich, strongly limonitized, remarkably large-sized (specimens are 30-70\% larger than those at their type localities) brachiopod-dominated (mainly Lacunosella and $\mathrm{N}$ ucleata) megafauna and a diverse crustacean microfauna, which indicates a shallow, nutrient-rich environment possibly linked to an uplifted block, and/or a hydrothermal vent.
\end{abstract}

Key words: Early Valanginian, volcanic basement, Mecsek Mts, Hungary, vent community, genetic model, large-sized brachiopods

\section{Introduction}

Cretaceous sediments in the Mecsek Mountains have been known for a long time (Fig. 1). Geologic mapping and research began during the 19th century (Hauer 1870), and Hofmann (1876) was the first to report Cretaceous volcanites from the area. Early research on the geology of the region was summarized by Vadász (1935) but the Cretaceous sediments and iron ore near Zengõvárkony were not yet known. In the 1930s the private entrepreneur Rezsõ Dezsõ discovered the Zengõvárkony iron ore, based on magnetic inclination measurement. After World War II intensive mining activities started at Zengõvárkony; however, due to the spatially restricted ore body and its comparatively low iron content, which did not even cover the direct costs of mining, the mine was closed and abandoned in the mid-1950s.

\footnotetext{
Address: L. Bujtor: H-1143 Budapest, Stefánia út 14, Hungary. Corresponding address: H-2030 Érd, Fenyõfa u. 63, Hungary, e-mail: zittelina@t-online.hu

Received: July 20, 2007; accepted: August 13, 2007
} 


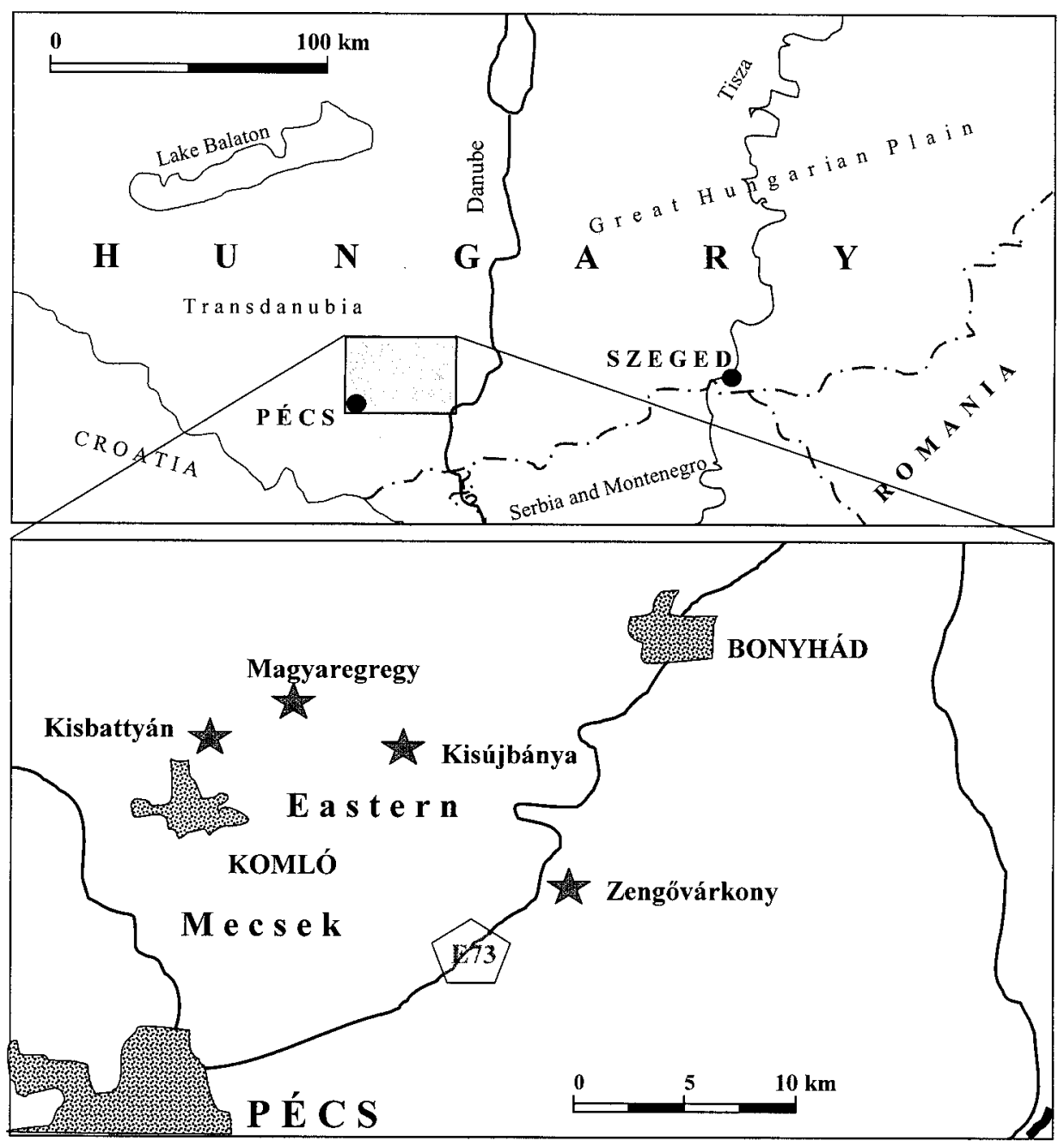

Fig. 1

Map of the Eastern Mecsek Mts indicating the Cretaceous outcrops

Sztrókay (1952) first investigated the possible origin of the iron ore at Zengõvárkony, and pointed out that the ore material is of biogenic origin. This conclusion encouraged further research. Pantó et al. (1955) examined the iron ore from a petrologic point of view and concluded that the accumulation of the limonitic material is linked primarily to ferriferous exhalations related to volcanic activity or upwelling of ferriferous hot-water solutions. They also pointed out the presence of abundant unidentified micro organisms in thin sections (Pantó et al. 1955; Pl. 2. figs 4, 5) and noted that the ore deposit is a stratiform accumulation 
on the surface of the volcanite. Molnár (1961) began the first detailed mapping, thoroughly investigated the petrology of the iron ore, and described the ore body. He pointed out that the thickness of the ore body varies between 0.1 and $1.2 \mathrm{~m}$ and that it can be traced only $600 \mathrm{~m}$ along strike (Fig. 2). The ore is situated on the top of the ankaramite-alkaline-basaltic volcanite cut by two valleys, and during the active mining (between 1954 and 1956) 24,850 tons of ore were excavated (M olnár 1961). Wein (1961) focused on the paleogeography of theEarly Cretaceous of the Mecsek Mts, and he pointed out that the former shoreline would have been located in a northwesterly direction; therefore the Zengõvárkony area faced toward the deeper basin. Later Wein (1965) refined his conclusion, pointing out that the former center of the volcanism could have been opposite Zengõvárkony, in a northwesterly direction.

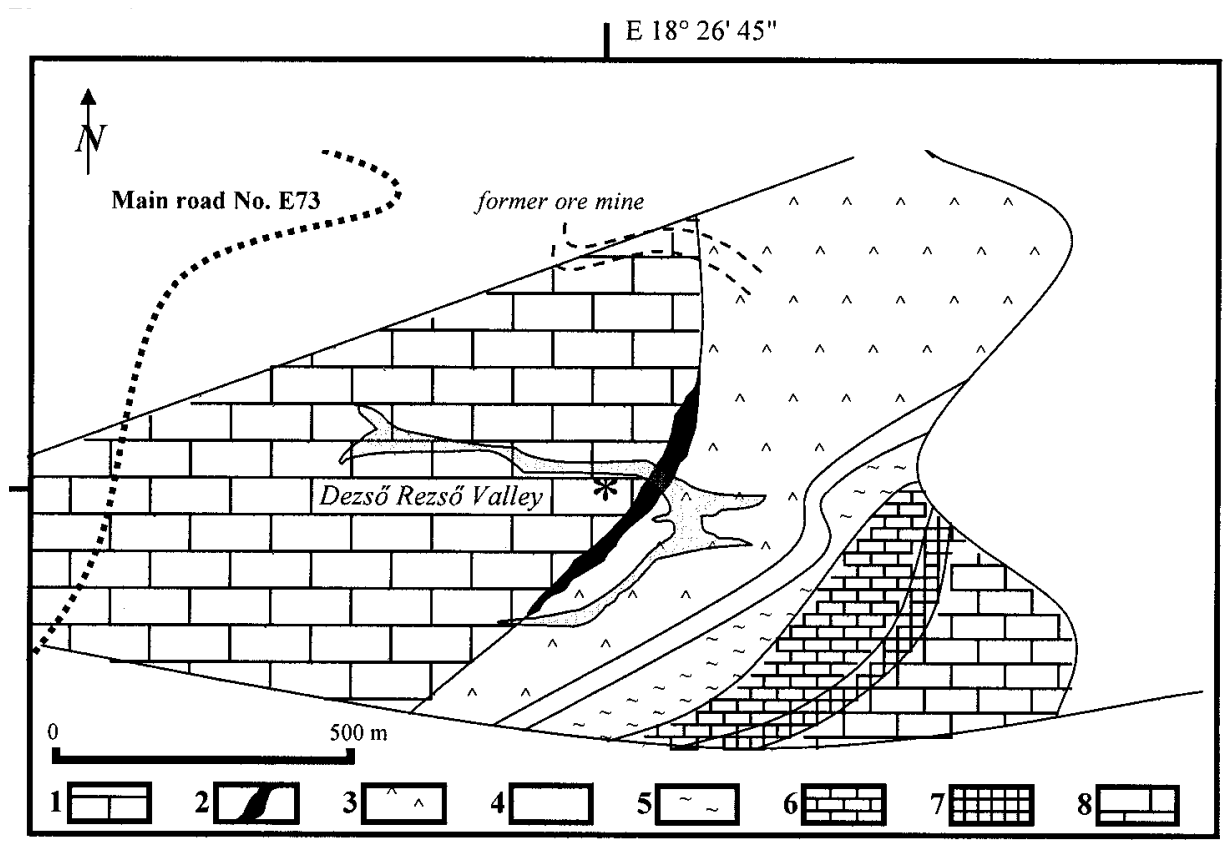

Fig. 2

Map of the Zengõvárkony iron ore deposit after Molnár (1961), modified and simplified. 1. Lower Cretaceous limestone; 2 . Early Valanginian iron ore deposit; 3. Lower Cretaceous alkaline volcanite (ankaramite); 4. Oxfordian-Tithonian marly limestone; 5. Bathonian-Callovian limestone; 6. Bajocian marly limestone; 7. Aalenian limestone; 8. older Jurassic sediments. The asterisk indicates the examined outcrop

The Zengõvárkony outcrop is situated in the southern Dezsõ Rezsõ valley and yielded the most striking Valanginian fauna of the Mecsek Mts (Fig. 3 - Bujtor 2006) shows the previously unknown section. The limonitized limestone layers were deposited on an altered pillow-lava surface. The volcanite is heavily altered 
but the $0.5-5 \mathrm{~cm}$ thick hyaloclastite crust and close to that its amygdaloidal structure (with vesicles $0.3-3 \mathrm{~mm}$ in diameter) is remarkable. The fauna is concentrated close to the lava surface, being allochthonous and strongly re deposited, dominated by strikingly large-sized brachiopods and fragmented ammonites (Bujtor 2006). The dominant component is the brachiopod fauna; all other faunal elements (cephalopods, gastropods, echinoderms) are subordinate. Bed 4 yielded the following brachiopods: Karadagithyris sp., Lacunosella hoheneggeri (Suess), M outonithyris sp. aff. moutoniana (D'Orbigny), Nucleata veronica Nekvasilová and Zittelina pinguicula (Zittel); cephalopods: "Lytoceras" sp. ind., "Phylloceras" sp. ind., H aploceratidae and $\mathrm{N}$ autiloidea gen. et sp. ind., and belemnitids, rarely gastropods, and echinid spines resembling to that of Balanocidaris rysacantha and Pseudocidaris clunifera (Szörényi 1965).

Regarding other fossils, Kolosváry (1961) reported Valanginian anthozoans from the iron ore mine, describing a new genus (Prototrochocyathus $n$. gen.), which may point to the Albian-Cenomanian species of Prototrochocyathus, although according to Kolosváry (1961, p. 497.) the Zengõvárkony specimens cannot be compared to the younger forms from either a morphologic or a stratigraphic point of view. Szörényi (1961) described echinid spines from the overlying marl beds, indicating Early Hauterivian age: Cidaris cherenensis Savin, Balanocidaris rysacantha (Gras.) and Pseu docidaris clunifera (Agassiz); however, she also reported (1961): Torynocrinus (T.) granulatus (Jaekel) and T. (Labiocrinus) labiatus Szörényi. Palik (1965) focused on the micro-organisms first illustrated by Pantó et al. (1955). She described six new ichnospecies as Favreina dispentochetarius, F. hexaochetarius, F. octoochetarius, Palaxius decaochetarius, P. tetraochetarius and P. triochetarius. Regarding this rich organic content, Palik (1965, p. 99) noted that crustacean excrement may have played a considerable role in the formation of the iron ore at Zengõvárkony. This seems also to be proved by the fact that such coprolites are found in great quantities in the iron ore as well as in the overlying beds. She also reported fossil crab antennae from thin sections, possibly belonging to Galatheidae. Beside the rich microfossil content, earlier research showed only weak indications on the abundant megafossil fauna related to the ore beds. While engaged in geologic mapping, Fülöp (in: Hetényi et al. 1968) was the first to report megafossils (brachiopods, mollusks and echinoderms): Cidaris sp., Duvalia dilatata Blainville, Neocomites neocomiensis D'Orbigny, Neolissoceras grasianum D'Orbigny, Olcostephanus astierianus D'Orbigny, Pleurotomaria sp., Rhynchonella mal bosi Pictet, R. sparsi costata Oppel, Terebratula aff. sal evensis Loriol and Torynocrinus sp., as well as microfossils (Tintinnopsella carpathica, Globigerina sp.) from the tailings of the ore mine. More recently Bujtor (2006) reported Valanginian brachiopods from Zengõvárkony revealing a strong faunal connection to the Pieniny Klippen Belt of the Western Carpathians, and presenting the first faunal evidence from the Mecsek Mts for the common development of the Tisza Unit and the Carpathians, already established through plate tectonics (cf. Golonka and Krobicki 2004; Haas and Péró 2004; Golonka et al. 2005). 
The first modern synthesis of the evolution and development of the region, with special reference to the Early Cretaceous was made by Császár (1992, 2002), who also recognized and proved the presence of former atoll-like structures (Császár and Turnšek 1996) and brought the Early Cretaceous of the Mecsek Mts into a broader context. Bércziné et al. (1997) also included the Zengõvárkony area in a paleogeographic reconstruction, indicating that Zengõvárkony was in shallower environment (within the slope), although they did not mention or explain the ore formation and its genesis. The present paper provides a synthesis based on previous work and the present author's latest research on the orerelated environment proposing a plausible explanation for its origin.

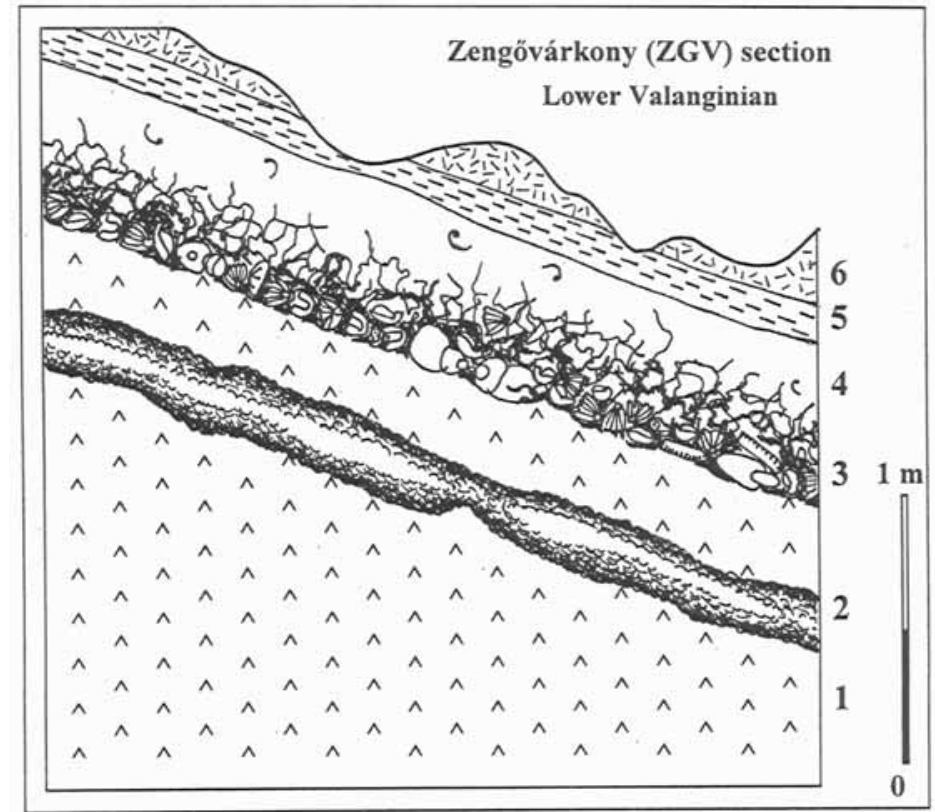

Fig. 3

The Zengõvárkony section after Bujtor 2006. 1. Altered alkaline basalt (ankaramite); 2. metasomatized limestone; 3. fossil-rich limonitized limestone; 4. marly limestone; 5. grayish brown clay; 6 . white tuffaceous layer

\section{M esozoic evolution and geologic setting of the $M$ ecsek $M$ ts}

Regarding the development of the region during the Early Cretaceous, the most significant tectonic movement was the detachment of the Tisza Microplate from the southern shelf of the European Plate, and the beginning of the significant rotation of the Tisza Mega-unit (Haas and Péró 2004) and the onset of alkaline rift-type basaltic volcanism. Therefore the Jurassic-Cretaceous development of the Mecsek Mts is linked to the development of the Tisza Mega-unit. By 
the end of the Jurassic period, the subduction of the Vardar Ocean began along its northern margin. Parallel to this, rifting also started in the Valais-MaguraPieniny-Mecsek zone (Kovács and Kázmér 1989), which formed troughs with oceanic or thinned continental crust. However, the collision of the Tisza unit with the Inner Carpathian terranes also ended during the late Jurassic (Golonka and Krobicki 2004; Golonka et al. 2005). The Late Jurassic sequence of the Mecsek Mts was deposited in a bathyal environment (Harangi 1989). As a result of rifting, extensive alkaline basaltic volcanism occurred in the Mecsek zone, producing volcanic, sub-volcanic and intrusive bodies, too (Juhász and Vass 1974). According to Bilik (1983) these rocks can be considered the products of continental rifting. In the Mecsek Mts volcanism may have begun during the Oxfordian (Fõzy et al. 1985). The volcanic activity became more intensive during the Late Jurassic and Berriasian (Pantó et al. 1955; Pantó 1961), and reached its acme during the Valanginian (Bilik 1974). Its products can also be recognized in core samples of exploration wells at the furthermost extents of the Mecsek zone (even as far as $200 \mathrm{~km}$ to the NE) (Császár et al. 1983), although surface outcrops are found only in the Mecsek Mts. However, the volcanic activity also produced mixed volcano-sedimentary rocks (Nagy 1967; Harangi 1989). In addition, Pantó (1961) pointed out that the alteration of products of the subsurface volcanic activity and iron hydroxide derived from synchronous exhalations produced local accumulation of iron ore. This scenario is a suitable theoretical framework for which the atoll-like structure and volcanic edifices are already proven (Császár and Turnšek 1996; Császár 2002), but no one has yet provided an explanation for the ore formation at Zengõvárkony. Regarding the topography of the basin, Harangi (1989) already pointed out that smaller and larger seamounts were formed, which produced a rough basin topography, while Bércziné et al. (1997) and Császár (2002) indicated that the Zengõvárkony environment was shallower than the basinal one at Kisújbánya. Császár (2002) also analyzed the bathymetry of the Lower Cretaceous formations of the Mecsek Mts, pointing out that the basin would have had a maximum depth of $500 \mathrm{~m}$. He did not consider the Zengõvárkony iron ore formation and its fauna, but indicated that the Zengõvárkony area would have been shallower compared to the basinal zone at Kisújbánya, which is in line with the conclusion of Bércziné et al. (1997).

\section{Ore petrology and geochemistry}

The first thorough investigation of the ore body revealed interesting information. According to Sztrókay (1952) the biogenic origin of the ore is proved by the consistently elevated phosphorous content, the presence of calcium carbonate, the lack of $\mathrm{Mg}$ and the relatively insignificant $\mathrm{Si}$ and $\mathrm{Al}$ contents. Typical minerals of the iron ore are goethite and lepidocrocite. The iron content of the excavated ore strongly varied between $18-65 \%$, and the average sample had ranges of $26.5-36.1 \%$ of iron, $0.63-3.2 \%$ of manganese, and $\mathrm{SiO}_{2}$ content of 8.7\% (Molnár 1961) based on the analysis of slot samples. 
The related Early Cretaceous volcanic rocks of the Mecsek M ts are the products of alkaline magmatism at the southern margin of the European Plate. This basalt is similar to alkaline basalt (ankaramite) of other intraplate areas (Harangi 1994). On the basis of this interesting environment, it appeared useful to carry out stable isotope analysis in order to highlight the possible genesis of the ore. It is remarkable that brachiopods played a significant role in vent/seep localities in the past (especially during the Cretaceous) and present. The remarkable size increase of the Zengõvárkony brachiopods (30-70\% larger than that of their type localities; see Fig. 4) also point to special paleoecological conditions. Carbon and oxygen isotope ratios are perfect indicators for the Mesozoic cold seep environments (cf. Campbell et al. 2002). Ratios both less than $-10 \delta^{13} \mathrm{C} \%$ and $-5 \delta^{16} \mathrm{O} \%$ are indicators of ancient cold seeps. In addition to stable isotopes, however, some brachiopods (e.g. the Cretaceous Peregrinella) also unequivocally point to cold seeps (Campbell and Bottjer 1995a). Peregrinella as an indicator of cold seeps has not yet been found, but the stable isotope analyses convincingly ruled out the cold seep hypothesis. Table 1 shows the result of stable isotope analysis performed at the University of Tübingen, Germany, according to the methods and standards of Spötl and Vennemann (2003). Although two samples

Table 1

Stable isotope analyses of some Zengõvárkony samples

\begin{tabular}{|c|c|c|c|c|c|}
\hline No. & Reference & Description of sample & $\mathrm{CaCO}_{3}$-content (\%) & $\delta^{13} \mathrm{C} \%$ (PDB) & $\delta^{16} \mathrm{O} \%$ (PDB) \\
\hline 1 & ZGV-A & Brachiopod-shell (Lacunosella sp.) & 78.2 & 0.45 & -2.96 \\
\hline 2 & ZGV-B & Brachiopod-shell (Lacunosella sp.) & 92.0 & 3.00 & -0.91 \\
\hline 3 & ZGV-C & $\begin{array}{l}\text { Microcrystalline calcite encrustation } \\
\text { on limonitic ore }\end{array}$ & 87.6 & -0.50 & -7.25 \\
\hline 4 & ZGV-D & Holoedric translucid calcite in vein & 84.8 & -5.86 & -7.77 \\
\hline 5 & ZGV-E & $\begin{array}{l}\text { Massive calcite infillings in limestone } \\
\text { fracture }\end{array}$ & 95.5 & -0.07 & -0.95 \\
\hline 6 & NGH-A & $\begin{array}{l}\text { Control sample from the Early } \\
\text { Valanginian of Kisújbánya (Bujtor } \\
\text { 1993). Ostreid shell from } \\
\text { conglomerate layer }\end{array}$ & 97.1 & 0.98 & -2.09 \\
\hline 7 & ZGV-F & $\begin{array}{l}\text { Yellowish-ochre microcrystalline } \\
\text { calcite in vein of limestone }\end{array}$ & 92.5 & -6.03 & -8.89 \\
\hline 8 & ZGV-G & $\begin{array}{l}\text { Holoedric calcite bonanza in vesicle } \\
(5 \times 2 \mathrm{~cm}) \text { of altered pillow-lava }\end{array}$ & 105.7 & -0.14 & -4.15 \\
\hline 9 & ZGV-H & $\begin{array}{l}\text { Holoedric transfused calcite crystals } \\
\text { in altered greenish volcanite matrix }\end{array}$ & 103.9 & -0.07 & -5.70 \\
\hline 10 & ZGV-I & $\begin{array}{l}\text { Massive milky white calcite } \\
\text { encrustation on hyaloclastite surface }\end{array}$ & 99.5 & 2.17 & -2.95 \\
\hline
\end{tabular}


(ZGV-D and -F) showed significant negative ratios, those data still fall within the field of burial diagenetic or meteoric alteration of isotope ratios (see fig. 16 of Campbell et al. 2002).

Thus the cold-seep hypothesis must be rejected, since stable isotope data only indicate early diagenetic alteration of stable isotope ratios of samples, and do not convincingly point to cold seep origin (see Campbell et al. 2002; Campbell 2006). Therefore the vent hypothesis became more plausible to explain the environment. Moreover, both the broader geological setting and the JurassicCretaceous development of the related tectonic unit indirectly support the vent hypothesis.

\section{M icro- and macrofauna}

Regarding the microfauna, the initial researchers thought that the biogenic structures were remnants of Dasycladaceae (Sztrókay 1952) or plants/crinoids (Molnár 1961), until Palik (1965) revealed their crustacean origin. The vast quantities and diversity of coprolites (incl. Palaxius) at Zengõvárkony raise the question of the bathymetry of the paleoenvironment. The ichnogenus Palaxius is closest to the coprolites of the recent Callichirus major (Say) that indicates shallow or even tidal zone (Pohl 1946), although the brachiopods may indicate slightly greater water depth (see below). However, Palik (1965) reported not only coprolites, but fossil crab antennae (Palik 1965; Pl. 2. figs 13-15) that can be assigned to the Galatheidea. Crabs play a very important role in the life of either vent or seep ecosystems. Van Dover et al. (1987) report that the population density of ventendemic bythograeid crabs is a useful indicator of the proximity of hydrothermal vents: the denser the population, the closer the hydrothermal vent is situated. Not only bythograeid crabs live near vents, however. Mullineaux and Manahan (1998) also report galatheid crabs (M unidopsis subsquamosa) from vents. Although the rich coprolite fauna at Zengõvárkony may point to a different group of decapods (thalassinids), it implies a unique environment with a rich and diverse decapod fauna. According to Palik (1965, p. 99) the crustacean excrements (present in great quantities in the iron ore) may have played a considerable role in the formation of the iron ore of Zengõvárkony.

Bujtor (2006) pointed out that the most abundant faunal elements are the remarkably large-sized specimens of Lacunosella and N ucleata. Krobicki (1994) noted that $L$. hoheneggeri in the Polish Outer Carpathians is typical for the sublittoral zone. Krobicki (1994) examined the paleoecology of L. hoheneggeri thoroughly. He noted that this species is known from both shallow-water, reeflike carbonate deposits and olistoliths in the Polish Outer Carpathians, where it represents nearly $80 \%$ of the entire brachiopod assemblage. It is very remarkable that in Zengõvárkony, L. hoheneggeri represents $61 \%$ of the brachiopod assemblage (Bujtor 2006). Krobicki (1994) also highlighted that this species is typical for the sublittoral zone and abundant in the Štramberk-type (reef-like) carbonates. 
Hence, the genus Lacunosella suggests a shallower marine environment (Krobicki and Wierzbowski 1996).

The crinoids Torynocrinus (T.) granulatus (Jaekel) and T. (Labiocrinus) labiatus Szörényi reported by Szörényi (1961) are cliff-dwelling forms, and are interesting elements within this environment.

Also notable is the rich microfossil content described by Palik (1965). Although based on strong recent analogies it cannot be concluded that the extinct animal that left Palaxius was a tidal one. According to Blau (1999) the closest trace-maker of the Palaxius decaochetarius ichnospecies is Callichirus major (Say, 1815). All C. species are tidal animals (Pohl 1946), known only from tidal and shallow-water zones (Abed-Navandi and Dworschak 1997, 1998). However, taking into consideration the large-sized brachiopods and the ore-related paleoenvironment, the abundance and diversity of coprolites in this environment may require other explanations. Van Dover (2000) reported rich decapod faunas at hydrothermal vents, which may explain the rich crustacean remnants (coprolites and crabantennae) at Zengõvárkony. On the other hand, Callender and Powell (1999) and Little et al. (2002) demonstrated that vent/seep communities were continuously ubiquitous in space and time from neritic to bathyal environments. This leaves the door open for the challenging possibility that the decapods that left the rich coprolite deposits were shallow marine and vent-restricted animals. Based on the rich coprolite remnants, crustaceans may have played as important role in the Zengõvárkony ecosystem as brachiopods did. Note again that the Early Cretaceous was an outstanding period for brachiopods. Campbell and Bottjer (1995b) reported 21 known hydrothermal vent and cold seep appearances with brachiopods from all over the world in Phanerozoic times, of which 11 occurred in the Early Cretaceous. Increasing amounts of data indicate that the Early Cretaceous vent/seep communities were dominated by brachiopods, mostly by rhynchonellids, as is the case at Zengõvárkony. Little et al. (2004) also report rhynchonellid brachiopods from a Pliensbachian fossil hydrothermal vent community in the Franciscan Complex in California (USA).

The Valanginian iron ore-related environment at Zengõvárkony was also dominated by large-sized brachiopods (see Fig. 4 and Bujtor 2006) and rich crustacean remnants (Palik 1965). Particularly for the Early Cretaceous, this fits well into a hypothetical vent community at Zengõvárkony. Remarkably, nektonic animals such as nautiloids and ammonoids also occur, but no bivalves have been reported so far. The megafaunal composition of the locality is shown in Fig. 5. It is remarkable that it makes no mention of coprolites; therefore the paleoecosystem cannot be reconstructed from that composite list alone. In any case this underlines the brachiopod dominance (73\%). It is notable that $16 \%$ of the total collected specimens were nektonic ones (ammonoids, nautiloids, and belemnitids); therefore the dominance of brachiopods among the benthic forms became more pronounced (87\%). 


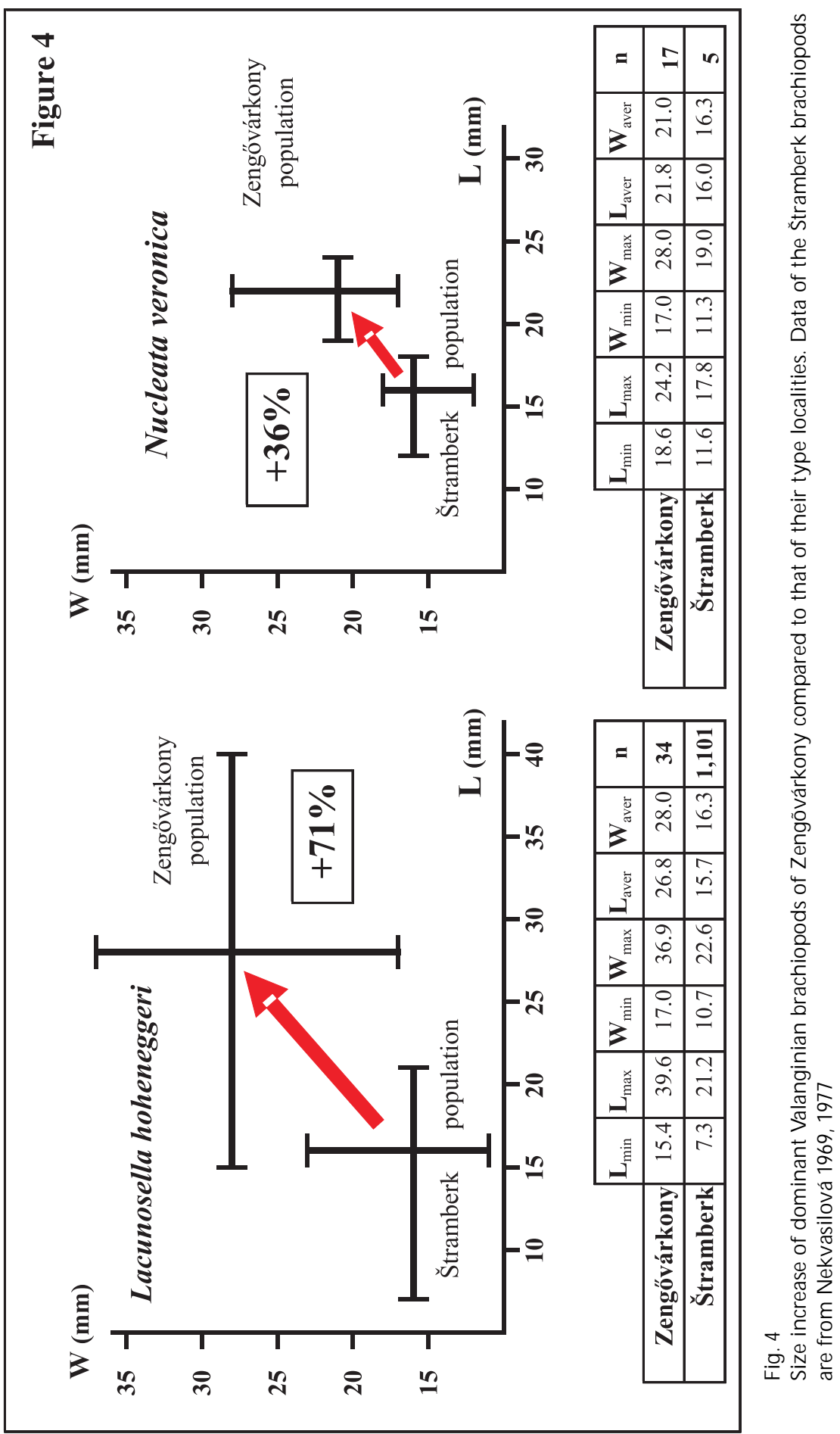




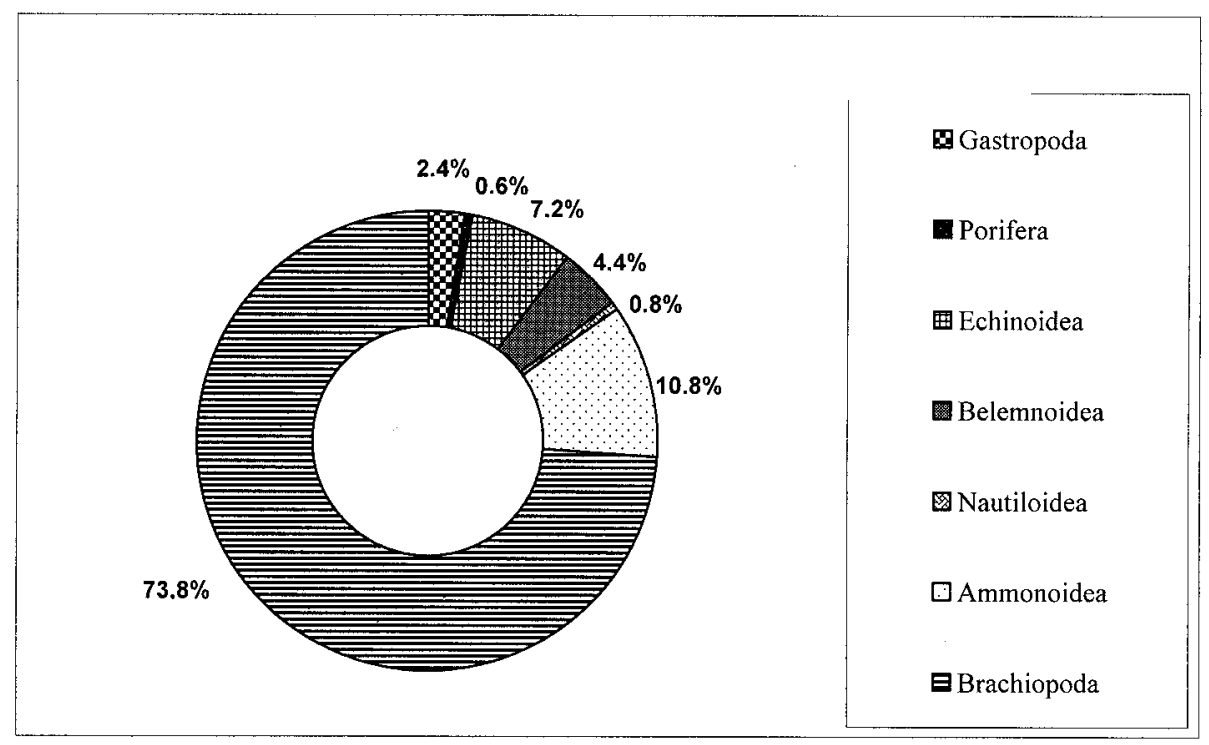

\section{Alternative hypotheses: hydrothermal vent vs. uplifted block}

Regarding the cross sections of Bércziné et al. (1997) and Császár (2002) the present author dropped the southeastern part of their model, using a completely new approach and paleorelief for the Apátvarasd-Zengõvárkony area. Fig. 6 shows the new approach, with special reference to the unique Zengõvárkony paleoenvironment.

It should be noted that Molnár (1961, p. 193) had already pointed out that the Zengõvárkony iron ore originated from exhalations related to volcanism. This paleocommunity and the related iron ore linked to volcanic exhalations strongly point to a former vent association. If one compares the ratio of the manganese and iron contents of the Zengõvárkony ore with that of the ratio of recent hydrothermal vents (Jannasch and Mottl 1985), they are very much alike. Even the geometry of the Zengõvárkony ore body is similar to that of the recent hydrothermal vent fields, based on recent observations of vents by Pfingst et al. (2000). Although no direct evidence has been found yet, the vent hypothesis appears to be the most convincing one. On top of the tectonically uplifted block, which was also the location of formation of subsurface lava-flows and hyaloclastite, a hydrothermal vent field is assumed to exist, with its brachiopoddominated fauna. Close to the edge of the block, and on the upper part of its slope, the cliff-dwelling crinoids would have lived. The primary consumers of the supposed brachiopod-dominated vent fauna were the thalassinid crabs, which 


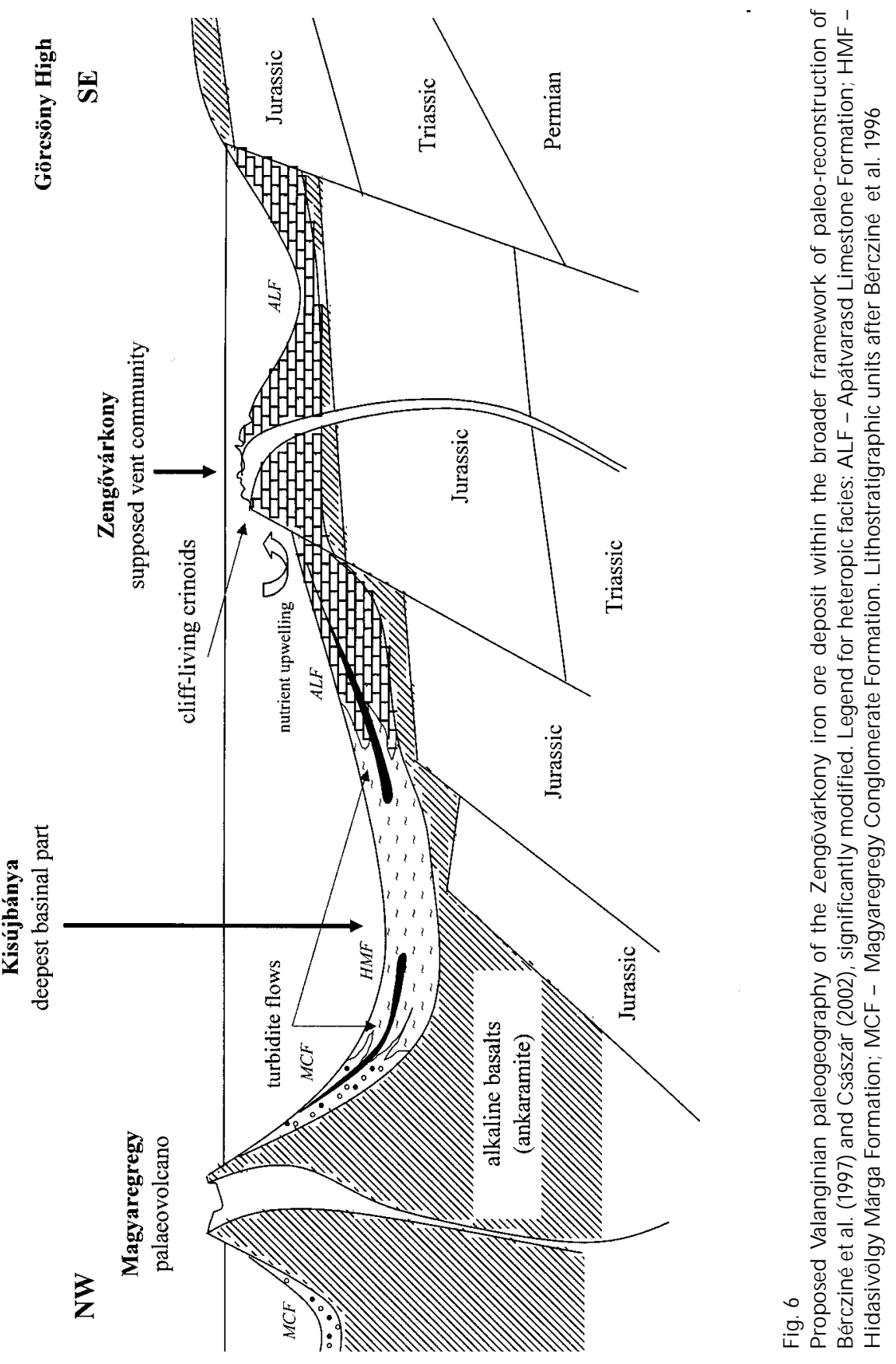

Central European Geology 50, 2007 
had a high diversity indicated by the 6 ichnospecies (described by Palik, 1965) and cephalopods.

If the vent hypothesis is rejected, only an uplifted block hypothesis would remain plausible. Indeed, seamounts and uplifted blocks have been described earlier from the region (Harangi 1989; Bércziné et al. 1997; Császár 2002), and the cliff-dwelling crinoids of Szörényi (1961) can be explained as well. The uplifted block hypothesis may explain the presence of cliff-dwelling crinoids. The upwelling cold streams along the uplifted block would also have provided the nutrient environment. However, other faunal elements do not fit easily into that scheme. Moreover, those crinoids may have been transported from other, shallower environs. In particular, the uplifted block hypothesis cannot explain the connection between the ore, its rich crustacean fauna and the anomalously large-sized brachiopods.

\section{Summary}

Dominant and remarkably large-sized Valanginian brachiopods, connected to an iron ore deposit at Zengõvárkony (Mecsek Mts, SE Hungary), were collected. The brachiopods are $30-70 \%$ bigger than those at their type localities. Other faunal elements such as cephalopods, crustaceans, echinoderms, and rarely gastropods created a unique former environment. All data based on the ecology of very different animal taxa unequivocally point to a shallow marine, nutrientrich, and volcanically active area related to subsurface volcanic exhalations of a spatially restricted uplifted block. This block would have been either an uplifted block (indicated by cliff-dwelling crinoids; cf. Szörényi 1961) of a sunken volcanic edifice (cf. Császár and Turnšek 1996) or an active hydrothermal vent location. Its rich fauna, especially the extremely dense crab content in the ore (coprolites and antennae; cf. Palik 1965) and the shallow-water indicator Lacunosella (Krobicki 1994: Krobicki and Wierzbowski 1996), appearing in great quantities and remarkably large size (cf. Bujtor 2006), all point to one possible environment: a hydrothermal vent. Stable isotope analyses unequivocally ruled out the cold seep origin. For the moment, any direct evidence is missing; moreover, none will be forthcoming, since during active mining (1954-56) the richest ore body was excavated. Nevertheless, it is worth calling attention to this enigmatic but tiny iron ore deposit, which is still not fully understood. Subsequent thorough investigation and proper new collection will either support or reject the presently proposed hydrothermal vent origin.

\section{Acknowledgements}

My special thanks to Géza Császár (Geological Institute of Hungary) for his comments, criticism and field support. I am especially thankful to Kathleen Campbell (University of Auckland, NZ) and Crispin Little (University of Leeds, 
GB) for the valuable comments and introduction into the world of hydrothermal vents and cold seeps. I am also extremely thankful to Steffen Kiel (Smithsonian Institution, USA) for valuable criticism, prudent remarks and a thorough improvement of this paper. Thanks are also due to Attila Vörös and József Pálfy (Nat. Hist. Mus. Hungary) for comments and criticism of the manuscript. My special thanks are due to my friend and colleague, Tamás Fehér, for his extensive support and help in both field work and improving the manuscript. I am grateful to the Geological Institute of Hungary for cleaning the outcrops and providing accommodation during field work.

Finally I am indebted to Géza Császár and Attila Vörös, referees of this paper for their thorough comments and in-depth remarks, which greatly improved it.

\section{R eferences}

Abed-Navandi, D., P.C. Dworschak 1997: First record of the thalassinid Callianassa truncata Giard and Bonnier, 1890 in the Adriatic Sea (Crustacea: Decapoda: Callianassidae). - Annalen des Naturhistorischen Museums in Wien, 99B, pp. 565-570.

Abed-Navandi, D., P.C. Dworschak 1998: First record of the thalassinids Callianassa acanthura Caroli 1946 and U pogebia mediterranea Noël, 1992 and of the hermit crab Paguristes streaensis Pastore, 1984 in the Adriatic Sea. - Annalen des Naturhistorischen Museums in Wien, 100B, pp. 605-612.

Bércziné Makk, A., I. Bilik, G. Császár, Á. Fekete, J. Haas, I. Horváth, J. I váncsics, E. Jocháné Edelényi, E. Juhász, P. Kisházi, J. Knauer, M.B. Knauerné Gellai, J. Konda, Gy. Lelkes, A. Mindszenthy, I. Nagy, K. Szentgyörgyi 1996: Magyarország litosztratigráfiai alapegységei Kréta (Lithostratigraphic basic units of Hungary. Cretaceous). - Magyar Állami Földtani Intézet, Budapest, $163 \mathrm{p}$.

Bércziné Makk, A.,G. Császár, A. Nusszer 1997: Stratigraphy and geological evolution of the Mesozoic basement of the Mecsek Zone in the Central Part of the Great Hungarian Plain (EastCentral Hungary). - Földtani Közlöny 126/2-3, pp. 185-207.

Bilik, I. 1974: Unterkretazische vulkanite des Mecsek-Gebirges. - Acta Geologica Academiae Scientiarium Hungaricae, 18/3-4, pp. 315-325.

Bilik, I. 1983: Lower Cretaceous submarine (rift) volcanism in the South Transdanubia (South Hungary). - In: Bisztricsány, E., Gy. Szeidovitz (Eds): Proceedings of the 17th Assembly of the European Seismological Committee, Budapest, 1980. Akadémiai Kiadó, Budapest, pp. 569-576.

Blau, J. 1999: FAVRIS - the interactive database on structured crustacean coprolites Justus Liebig Universität, Gießen, Germany. www.unigiessen.de/ gg13/FAVRIS/DECAPODA/PALAXIUS/PX OPT.HTM [2006-10-09].

Bujtor, L. 2006: Early Valanginian brachiopods from the Mecsek Mts (southern Hungary) and their paleobiogeographical significance. - Neues Jahrbuch für Geologie und Paläontologie, Abhandlungen, 241/1, pp. 111-152.

Callender, W.R., E.N. Powell 1999: Why did ancient chemosynthetic seep and vent assemblages occur in shallower water than they do today? - International Journal of Earth Sciences, 88, pp. 377-391.

Campbell, K.A. 2006: Hydrocarbon seep and hydrothermal vent paleoenvironments and paleontology: Past developments and future research directions. - Paleogeography, Paleoclimatology, Paleoecology, 232, pp. 362-407.

Campbell, K.A., D.J. Bottjer 1995a: Peregrinella: an Early Cretaceous cold-seep-restricted brachiopod. - Paleobiology, 21/4, pp. 461-478. 
Campbell, K.A., D.J. Bottjer 1995b: Brachiopods and chemosymbiotic bivalves in Phanerozoic hydrothermal vent and cold seep environments. - Geology, 23/4, pp. 321-324.

Campbell, K.A., J.D. Farmer, D. Des Marais 2002: Ancient hydrocarbon seeps from Mesozoic convergent margin of California: carbonate geochemistry, fluids and paleoenvironments. Geofluids, 2, pp. 63-91.

Császár, G. 1992: A Tisza-egység urgon fáciesû képzõdményei (Urgonian facies of the Tisza Unit). Acta Geologica Hungarica, 35/4, $150 \mathrm{p}$.

Császár, G. 2002: Urgon formations in Hungary with special reference to the Eastern Alps, the Western Carpathians and the Apuseni Mountains. - Geologica Hungarica ser. Geologica, 25, $209 p$.

Császár, G., D. Turnšek 1996: Vestiges of atoll-like formations in the Lower Cretaceous of the Mecsek Mountains, Hungary. - Cretaceous Research, 17, pp. 419-442.

Császár, G., I. Fridelné-Matyók, I. Kovácsné-Bodrogi 1983: Cretaceous rock drilled at Nagybaracska (S Hungary). - MÁFI Évi Jel. 1981, pp 213-238.

Fõzy, I., Cs. Lantai, K. Schlemmer 1985: A Pliensbachian-Lower Cretaceous profile at Zobákpuszta (Mecsek Mts, Hungary). - Annales Universitatis Scientiarium Budapestinensis de Rolando Eötvös nominate, sectio Geologica, 25, pp. 97-115.

Golonka, J., M. Krobicki 2004: Jurassic paleogeography of the Pieniny and Outer Carpathian Basins. - Rivista Italiana di paleontologia e Stratigrafia, 110/1, pp. 5-14.

Golonka, J., L. Gahagan, J. Krobicki, F. Marko, N. Oszczypko, A. Slaczka 2005: Plate-tectonic evolution and paleogeography of the circum-Carpathian region. - In: Golonka, J., F.J. Picha (Eds): The Carpathians and their foreland. Geology and hydrocarbon resources: AAPG Memoir, 84, pp. 11-46.

Haas, J., Cs. Péró 2004: Mesozoic evolution of the Tisza Mega-unit. - International Journal of Earth Sciences, 93/2, pp. 297-313.

Harangi, Sz. 1989: Redeposited volcanoclastic limestone in the Eastern Mecsek Mts, southern Hungary. - Acta Mineralogica-Petrographica Szeged, 29, pp. 81-93.

Harangi, Sz. 1994: Geochemistry and petrogenesis of the Early Cretaceous continental rift-type volcanic rocks of the Mecsek Mountains, South Hungary. - Lithos, 33/4, pp. 303-321.

Hauer, F. 1870: Das Gebirge von Fünfkirchen. - In: Hauer, F.R. (Ed.): Geologische Uebersichtkarte der österreichisch-ungarischen Monarchie. Blatt VII. Ungarisches Tiefland. Jahrbuch der kaiserlich-königlichen geologischen Reichsanstalt, 20, pp. 491(29)-495(33).

Hetényi, R., G. Hámor, I. Nagy 1968: Magyarázó a Mecsek hegység földtani térképéhez, 10 000-es sorozat. Apátvarasd (Explanatory notes to the geological maps of the Mecsek Mountains. Series 1:10 000. Apátvarasd). - Magyar Állami Földtani Intézet, 55 pp.

Hofmann, K. 1876: Eruptív kõzetek a Mecsek hegységbõl (Die Eruptivgesteine des Mecsekgebirges) - In: Böckh, J. (Ed.): Pécs város környékének földtani és vízi viszonyai (Die geologische und Wasserverhältnisse des Umgebung von Fünfkirchen). - Magyar Királyi Földtani Intézet Évkönyve, 4, pp. 129-287.

Jannasch, H.W., M.J. Mottl 1985: Geomicrobiology of deep-sea hydrothermal vents. - Science, 229/4715, pp. 717-725.

Juhász, Á., G. Vass 1974: Mesozoische Ophiolithe im Beckenuntergrund der Grossen Ungarischen Tiefebene. - Acta Geologica Academiae Scientiarium Hungaricae, 18/3-4, pp. 349-358.

Kolosváry, G. 1961: Quelques Madréoporaires fossils intéressants, nouveaux en Hongrie. - MÁFI Évi Jel. 1957-58, pp. 497-503.

Kovács, S., M. Kázmér 1989: Triassic and Jurassic oceanic/paroceanic belts in the Carpathian-Pannonian region and its surroundings. - In: Sengör, A.M.C. (Ed.): Tectonic evolution of the Tethyan Region. - Kluwer Academic Press, London, pp. 77-92.

Krobicki, M. 1994: Stratigraphic significance and paleoecology of the Tithonian-Berriasian brachiopods in the Pieniny Klippen Belt, Carpathians, Poland. - Studia Geologica Polonica, 106, pp. 89-156. 
Krobicki, M., A. Wierzbowski 1996: New data on stratigraphy of the Spisz Limestone Formation (Valanginian) and the brachiopod succession in the lowermost Cretaceous of the Pieniny Klippen Belt, Carpathians, Poland. - Studia Geologica Polonica, 109, pp. 53-67.

Little, C.T.S., K.A. Campbell, R.J. Herrington 2002: Why did ancient chemosynthetic seep and vent assemblages occur in shallower water than they do today? - Comment. International Journal of Earth Sciences, 91, pp. 149-153.

Little, C.T.S., T. Danelian, R.J. Herrington, R.M. Haymon 2004: Early Jurassic hydrothermal vent community from the Franciscan Complex, California. - Journal of Paleontology, 78/3, pp. 542-589.

Molnár, J. 1961: A zengõvárkonyi vasérckutatás (Iron ore exploration of Zengõvárkony). Bányászati Lapok, 94/3, pp. 187-194.

Mullineaux, L., D. Manahan 1998: Deep-sea diaspora. - Oceanus, 41/2, pp. 6-9.

Nagy, I. 1967: A felsõjura képzõdmények és a kréta vulkanitok viszonya a Mecsekben (Relations of the Upper Jurassic formations and the Cretaceous volcanites in the Mecsek Mountains). MÁFI Évi Jel. 1965, pp. 149-168.

Nekvasilová, O. 1969: N ew information on the occurrence of brachiopods at Stramberk (Stramberg), Moravia (Czechoslovakia, Upper Tithonian and Lower Cretaceous). - Vestnik ústrednyh Ústavu geol., 44, pp. 261-263.

Nekvasilová, O. 1977: Rhynchonellida (Brachiopoda) from the Lower Cretaceous of Štramberk (Czechoslovakia). - Sborník geol. Ved, Paleontol., 19, pp. 45-77.

Palik, P. 1965: Remains of crustacean excrement from the Lower Cretaceous of Hungary. Micropaleontology, 11/1, pp. 98-104.

Pantó, G. 1961: Mezozoós magmatizmus Magyarországon (Mesozoic magmatism in Hungary). MÁFI Évk., 49/3, pp. 785(215)-799(229).

Pantó, G., K. Varrók, G. Kopek 1955: A zengõvárkonyi vasérckutatás földtani eredményei (Geological results of the iron ore exploration of Zengõvárkony). - Földtani Közlöny, 85/2, pp. 125-144.

Pfingst, T., C.L. Van Dover, R. Haymon, K. Macdonald, D. Wright 2000: Characteristics of hydrothermal vent communities. - 8th Deep-Sea Biological Symposium, Martin Ryan Marine Research Institution, Ireland

Pohl, M.E. 1946: Ecological observations on Callianassa major Say at Beaufort, N orth Carolina. Ecology, 27/1, pp. 71-80.

Spötl, Ch., T.W. Vennemann 2003: Continuous-flow isotope ratio mass spetrometric analysis of carbonate minerals. - Rapid Communications in Mass Spectrometry, 17, pp. 1004-1006.

Szörényi, E. 1961: Magyarországi mezozoós echinodermaták (Mesozoic Echinoidea of Hungary). MÁFI Évk., 49/1, pp. 255-259.

Szörényi, E. 1965: Échinides du Crétacé Inférieur de la Hongrie. - Geologica Hungarica ser. Paleont, 29-32, pp. 293-367.

Sztrókay, K. 1952: Mecseki vasércképzõdés (Iron ore genesis in the Mecsek Mountains). - Magyar Tudományos Akadémia Mûszaki Osztályának Közleményei, 3, pp. 11-230.

Vadász, E. 1935: Das Mecsek-Gebirge. Geologische Beschreibung Ungarischer Landschaften I. Königliche Ungarische Geologische Anstalt, $180 \mathrm{p}$.

Van Dover, C.L. 2000: The ecology of deep-sea hydrothermal vents. - Princeton Univ Press, Princeton, $424 \mathrm{p}$.

Van Dover, C.L., P.j.S. Franks, R.D. Ballard 1987: Prediction of hydrothermal vent locations from distributions of brachyuran crabs. - Limnology and Oceanography, 32, pp. 1006-1010.

Wein, Gy. 1961: A szerkezetalakulás mozzanatai és jellegei a Keleti-Mecsekben (Moments and characters of the structural development in the Eastern Mecsek Mountains). - MÁFI Évk., 49/3, pp. 759-768.

Wein, Gy. 1965: A Mecsek-hegység "Északi Pikkely"-ének földtani felépítése (Geological setting of the "Northern Imbrication" in the Mecsek Mountains). - MÁFI Évi Jel. 1963, pp. 35-52. 